\title{
ПРОБЛЕМЫ СОВРЕМЕННОГО ЦЕННОСТНОГО ОТНОШЕНИЯ К МАТЕРИНСТВУ В РОССИИ
}

\author{
А. Р. Субочева, Н. В. Каргина \\ Московский гуманитарный университет
}

Аннотация: В статье рассматривается проблема демографического кризиса в России, как следствие утраты ценности материнства современной молодежью.

Статья подготовлена на основе доклада автора на ХІІІ Международной научной конференции «Высшее образование для ХХІ века» (8-10 декабря 2016 г. в Московском гуманитарном университете).

Ключевые слова: психология материнства; материнство; социильные ценности; демографический кризис

\section{PROBLEMS OF CONTEMPORARY ATTITUDE TO MOTHERHOOD VALUES IN RUSSIA}

\author{
A. R. Subocheva, N. V. Kargina \\ Moscow University for the Humanities
}

\begin{abstract}
The article deals with the problem of the demographic crisis in Russia, caused by the loss of motherhood value among modern young people.

The article is prepared on the basis of the author's presentation given at the 13th International Scientific Conference «Higher Education for the 21st Century» (8-10 December 2016, Moscow University for the Humanities).

Keywords: psychology of motherhood; motherhood; social values; demographic crisis
\end{abstract}

Во всем мире, и Россия не исключение, материнство считается основным предназначением женщины, высшим воплощением женского начала. Образ матери неоднократно воспет в различных произведениях искусства, и сама тема материнства, его ценность и связанные с этим феноменом вопросы в настоящее время являются объектом пристального внимания и изучения не только психологии (Котова, 2013) и культурологии, но и других наук - философии, медицины. Отношение к материнству, как к одной из важнейших духовно-нравственных ценностей является традиционным для нашей страны.

Однако в настоящее время эта традиция трепетного отношения $\mathrm{k}$ материнству постепенно нивелируется. Утрачивается понимание материнства, как ценности. В последние годы в России сложилась достаточно 
сложная демографическая ситуация. По данным Всероссийской переписи населения 2010 г. численность населения России уменьшилась на 2,3 миллиона человек в сравнении с переписью населения 2002 г. Согласно данным Министерства экономического развития Российской Федерации, в 2014-2015 гг. в стране начало увеличиваться число умерших, снизилось число рожденных, и, как следствие, увеличился отрицательный естественный прирост населения и численность постоянного населения. Несмотря на то, что сегодня правительство страны принимает множество законов и инициатив, направленных на увеличение рождаемости, можно с уверенностью говорить о сильной убыли населения. При этом следует отметить, что даже миграционный прирост не покрывает численные потери. Значит, сложная демографическая ситуация имеет комплексный характер и решать ее надо всесторонне. Немалое значение в решении проблемы имеет проблема жизненных ценностных приоритетов - внутренних регуляторов поведения человека, его целей, идеалов и ценностей.

В нашей стране существует двойственное отношение к институту материнства. С одной стороны, еще с советских времен существует почетное звание «Мать-героиня», однако при этом с детства девочек поощряют к достижению независимости, особенно приводящей к финансовому и карьерному росту, а женщина, осознанно посвящающая себя семье, часто воспринимается обществом, как человек ограниченный, не имеющий возможности и способностей достичь карьерных высот. И в сознании современных девушек бытуют установки, что сначала нужно добиться профессиональных успехов, а уже потом заводить семью и детей. В результате успешные бизнес-леди и молодые начальницы часто не могут найти подходящую кандидатуру в мужья и остаются одинокими. Некоторые из них решаются стать матерями-одиночками в достаточно зрелом возрасте 35-40 лет, но часто к этому моменту накапливаются биологические изменения в организме и возникают проблемы с репродуктивной функцией.

Уменьшение ценности материнства в глазах населения детородного возраста и, особенно, в глазах молодых женщин на сегодняшний момент стоит особенно остро. Все большую популярность набирает субкультура чайлдфри (от англ. child free - свободный от детей), которая характеризуется осознанным, необусловленным никакими физиологическими проблемами нежеланием заводить детей. Хотя чайлдфри для нашей страны явление достаточно новое, исследователи отмечают большое количество групп в социальных сетях. Только «Вконтакте» на сегодняшний день насчитывается более 100 групп с данной тематикой, что объединяет тысячи людей по всей России. В 2013 г. прокуратура Санкт-Петербурга сообщила, что руководство «ВКонтакте» заблокировало по её требованию несколько групп и один личный аккаунт, в которых общались сторонники идеологии 
чайлдфри. Прокуратура сочла, что в данных сообществах содержалась информация, которая отрицает семейные ценности, формирует негативное отношение к родителям и призывает к противозаконным действиям.

Также необходимо отметить, что в последнее время распадается огромное число молодых семей, увеличивается количество детей-сирот, в том числе и детей-сирот при живых родителях. Все чаще в СМИ можно встретить шокирующие статьи о случаях жестокого обращения с детьми, зачастую совершаемыми одним из родителей, нередко матерью.

Как мы видим, проблема снижения ценности материнства в России в данный момент стоит очень остро и является на наш взгляд одной из самых актуальных. Так почему же, несмотря на то, что материнство является базовым жизненным предназначением женщины, важной социально-психологической функцией, многие женщины сознательно отказываются от этого?

Несмотря на всю важность и необходимость феномена материнства область знаний, связанная с психологическими аспектами материнства и подготовки к нему, является до сих пор малоизученной областью отечественной науки. Первоначально материнство как отдельное направление исследований стало рассматриваться в естественных науках: медицине, физиологии, биологии поведения, однако к середине XX века в связи с возросшим интересом к данной области знания сфера материнства стала объектом изучения и гуманитарных наук: психологии, социологии и педагогики.

Среди психологов-исследователей, которые посвятили свои труды изучению данного вопроса, следует выделить труды Г. Г. Филипповой (Филиппова, 1999), так как в результате ее исследований в 1990-е гг. в отечественной психологии возникло научное направление - «психология материнства» и именно ей был введен данный термин. В рамках этого направления материнство рассматривается, как «самостоятельная психологическая реальность, принадлежащая матери как субъекту» (Филиппова, 1999: 8).

Так же хотелось бы отдельно отметить статью Г. Г. Филипповой «Материнство и основные аспекты его исследования в психологии» (Федотова, 2001). Данная статья представляет собой интерес тем, что в ней в достаточно лаконичном виде собраны и обобщены исследования по проблеме изучения феномена материнства в психологии и смежных отраслях науки. В статье рассмотрены два ключевых направления исследований: материнство как обеспечение условий для развития ребенка (культурноисторические, психологические и биологические аспекты материнства) и материнство как часть личностной сферы женщины (материнство рассматривается как стадия половозрастной идентификации). 
Возрастание общественного интереса к изучению материнства, как базовой ценности определяется тем, что есть тенденция к постепенной утрате понимания и принятия этого феномена. Повсеместно, а не только в России происходит размывание и снижение ориентации молодых женщин в данном вопросе. Этому способствуют следующие факторы: влияние негативного родительского опыта (например, измены, развод или частые конфликты), ослабление ценностной ориентации на брак на уровне государственной политики (отсутствие последовательной, научно-обоснованной программы подготовки молодежи к семейной жизни в образовательных институтах), общественное принятие различных внебрачных форм взаимоотношений (например, гражданский брак). Все эти факторы в совокупности с не всегда благополучным материальным положением женщины приводят к тому, что формируется негативное отношение к материнству.

Воспитание семейных ценностей начинается в семье, однако не менее значимую роль в этом процессе играют общественные институты. Следует прививать и развивать ответственное отношение к материнству и отцовству с самого раннего детства - с дошкольных образовательных учреждений и на протяжении всего периода образования и воспитания молодежи. Также надо обратить внимание, что огромное воздействие на формирование отношения к материнству оказывают средства массовой информации, особенно телевидение и Интернет. Именно на эту сферу необходимо уделить значительное влияние, так как здесь открывается широкое поле для возрождения ценностей материнства и отцовства, укрепления нравственности и морали в молодежной среде и популяризацию многодетной семьи.

Для того, чтобы вернуть материнство в ряд основных ценностей современной молодежи вообще и молодых женщин, в частности, необходимо соблюсти ряд условий.

Прежде всего, отмечая важную роль СМИ, необходимо на государственном уровне заниматься пропагандой ценностей материнства. Можно использовать образы медийных личностей, делая акцент на их семейственности. Поскольку часто молодежь выбирает себе примеры для подражания именно в этой среде, то образы семейных медийных личностей будут способствовать популяризации семейных ценностей. Также следует обогатить позитивными образами информационное пространство в образовательных учреждениях и женских консультациях для увеличения объема знаний о том, что собой представляет благополучная семья, как правильно воспитывать детей и сохранять гармонию в семейных отношениях.

Материнство не является врожденной потребностью и ценностью 
для женщины, значит необходимо способствовать правильному формированию данной ценности на уровне семьи и развивать эту ценность в образовательных учреждениях, что будет способствовать преемственности воспитательных воздействий, осознанию ценности материнства, как важной ценности не только для каждого конкретного человека, но и для общества в целом, и формированию мотивационно-смысловой составляющей ценностного отношения к материнству. Для реализации этих задач следует ввести уроки полового воспитания и вернуть уроки домоводства, но развернуть их в ключе подготовки к построению семейных отношений, моделированию молодежью отношения к семье, как к перспективной возможности, а не как дополнению к карьере.

Реализация данной программы, а именно введение в учебные планы образовательных учреждений различных уроков, курсов, разделов или просто обсуждения тем, которые будут не просто ориентированы на семейные ценности, а будут целенаправленно формировать у подрастающего поколения ценности материнства, отцовства и семьи с помощью теоретической и практической подготовки молодежи к созданию и сохранению семьи. Бытует мнение, что в нашей стране никто никогда не занимался вопросом полового воспитания. Однако это неверно: в 20-30-е годы XX века в Советской России большое внимание уделялось именно вопросам воспитания молодежи. Например, данному вопросу большое внимание уделял П. П. Блонский, известный советский психолог, он считал, что нужно уделять особое внимание формированию у подрастающего поколения нравственного идеала семьянина. А в 1980-е годы Министерством просвещения СССР и Академией педагогических наук СССР в школы широко внедрялась типовая программа «Этика и психология семейной жизни» для старшеклассников. Были введены обязательные курсы «Гигиеническое и половое воспитание», основными задачами которых были формирование полового самосознания и подготовка к ответственному супружеству, т. е. понимание своих ролей матери и отца.

Подобные курсы необходимо проводить также для будущих мам на уровне женских консультаций, так как приобретение знаний и умений не только в области удовлетворении потребностей младенца, но и в решении разного рода семейных проблем и преодоления конфликтных ситуаций, с которыми столкнется молодая семья после появления детей, позволит сохранить семью и улучшить семейный микроклимат, что будет благотворно не только для ребенка, но и для всех членов семьи.

Также не следует забывать про материально-техническую поддержку на государственном уровне. Безусловно, поддержка оказывается и сегодня, но часто в недостаточном объеме. На сегодняшний день в нашей стране традиционными проблемами в данной сфере являются слабая стартовая 
материально-финансовая поддержка молодых семей, неравномерное качество оказания медицинских услуг (в зависимости от региона), проблемы с очередями в образовательные учреждения. Для решения этих проблем необходимо увеличить размер единовременных выплат и пособий на ребенка, предоставить льготные условия для оформления ипотеки или досрочного получения жилья. Необходимо увеличить количество мест в детских садах, вернуть институт яслей или предложить льготы предприятиям, которые готовы организовать подобные учреждения для своих сотрудниц, как это реализовывалось в советское время.

Проведенная нами работа обозначила актуальность и очертила основные вопросы изучаемой проблемы. Несмотря на то, что, казалось бы, материнство - одна из основных социальных ценностей и должна быть заложена биологически, на нее влияют общественные нормы и ценности. Проблема утраты ценности материнства и, как следствие, затяжной демографический кризис в России - это комплексная проблема, которая требует комплексного подхода к ее решению. В данной статье было наглядно показано, что назрела необходимость в проведении исследований ценностной ориентации молодых женщин. Без проведения исследований и качественной интерпретации полученных данных будет затруднительно планировать реализацию программ, направленных на решение данного вопроса. А решение данного вопроса, безусловно, является важным не только при психодиагностической работе с каждой конкретной женщиной, но и очень важно для развития и существования общества в целом.

\section{СПИСОК ЛИТЕРАТУРЫ}

Котова, А. В. (2013) Особенности онтогенеза материнства и психологической готовности к материнству у беременных женщин с различными соматическими заболеваниями // Знание. Понимание. Умение. № 1 . С.264-267.

Филиппова, Г. Г. (1999) Психология Материнства. Концептуальная модель. М. : Изд-во Ин-та молодежи. 286 с.

Филиппова, Г. Г. (2001) Материнство и основные аспекты его исследования в психологии // Вопросы психологии. № 2. С. 22-37.

Дата поступления: 28.11.2016 2. 
Субочева Алина Романовна - магистрант 1 года обучения по специальности психологии Московского гуманитарного университета. Адрес: 111395, Россия, г. Москва, ул. Юности, д. 5. Тел: +7 (499) 374-67-20, +7 (905) 771-88-76. Эл. адрес: subocheva@bk.ru

Каргина Наталья Вячеславовна - кандидат психологических наук, доцент, доцент кафедры общей психологии и истории психологии Московского гуманитарного университета. Адрес: 111395, Россия, г. Москва, ул. Юности, д. 5. Тел: +7 (499) 374-67-20, +7 (905) 501-12-31. Эл. адрес: kanat99@ya.ru

Subocheva Alina Romanovna, Graduate Student, Department of General Psychology and History of Psychology, Moscow University for the Humanities. Postal address: 5, Yunosti st., Moscow, Russian Federation 111395. Tel.: +7 (499) 374-67-20, +7 (905) 771-88-76. E-mail: subocheva@bk.ru

Kargina Natalia Vyacheslavovna, Candidate of Psychology, Associate Professor, Assistant Professor, Department of General Psychology and History of Psychology, Moscow University for the Humanities. Postal address: 5, Yunosti st., Moscow, Russian Federation 111395. Tel.: +7 (499) 374-67-20, +7 (905) 50112-31.E-mail:kanat99@ya.ru

\section{Для цичтирования:}

Субочева А. Р., Каргина Н. В. Проблемы современного ценностного отношения к материнству в России [Электронный ресурс] // Научные труды Московского гуманитарного университета. 2017, № 1. URL: http://journals.mosgu.ru/trudy/article/view/396 (дата обращения: дд.мм.гг.). DOI: 10.17805/trudy.2017.1.5 